\title{
Entrepreneurship and Innovation Path of Private College Students' Library Service
}

\author{
Jing Xiong \\ Yangtze University of Engineering and Technology.No. 85 Xueyuan Road, Jingzhou, Hubei. \\ liucm@yangtzeu.edu.cn
}

Keywords: Private universities; Library; College students; Entrepreneurship and innovation; Four in one; Personalized service

\begin{abstract}
In order to provide quality services to the students entrepreneurial innovation, research paper, literature and other methods, the proposed path of entrepreneurship and innovation for the Private University Students' library service proposition that public entrepreneurship at Peoples innovative new situation, shouldering the Private University Library the new mission is to play to their strengths, to provide personalized support in the literature and information services for university students entrepreneurship and innovation. Private University Library Service to clear direction, improve service warm, improve service levels, service guide change and maintain sustainable development, effective service to try a new path, namely: changing ideas, build a service platform, to build four in one service network, to carry out one personalized information services.
\end{abstract}

\section{Private University Library New Mission in the Mass Start Peoples Innovation}

Premier Li Keqiang at the September 2014 Summer Davos Forum, the implementation of innovation-driven development strategy, create a favorable social environment for innovation and entrepreneurship. March 5, 2015 in the government work report Premier Li Keqiang put forward: to promote the "public entrepreneurship and innovation", "both can expand employment, increase income, but also conducive to the promotion of social justice and the longitudinal flow." In addressing entrepreneurship and innovation culture, emphasizing "Let people in the process of wealth creation, and better realize their own values and spiritual pursuits." [1]. June 11, 2015, "the State Council on the highly entrepreneurial innovation and vigorously promote the public a number of policies and measures opinions" (Guo Fa [2015] No. 32) clearly states that "promoting popular entrepreneurship and innovation, is the source of development, but also enriching road policy, fair measure, the power for the promotion of economic restructuring, to create a new engine development, and enhance the development of new power, take the path of innovation-driven development of great significance, is steady growth, expanding employment and stimulate hundreds of millions of their wisdom and creativity promote social longitudinal flow, an important measure of fairness and justice. "[2]" all localities and departments should be based on reform and innovation, adhere to the demand-oriented institutional mechanisms to solve various problems faced by entrepreneurial innovation fundamentally, to jointly promote the public venture, Peoples innovation to flourish. "As early as 2012, the Ministry of Education issued a "do a good job on the Ministry of Education," undergraduate teaching project "National Students' Innovation and Entrepreneurship Training program implementation of the notice" (teach high letter [2012] No. 5) [3] in the National College (Education subordinate institutions as the main body) to carry out innovation and entrepreneurship in the implementation of the training program students work first started 117 colleges and universities, and published in a special section of innovation and entrepreneurship training program students Department of Education Web site by 14,557 student projects, including innovative training program 12869, 1481 entrepreneurship training programs, business practices project 207 [4]. From 2012, the Ministry of Education project approval year project innovation and entrepreneurship group of university students, promoting innovation and entrepreneurship students to expand activities to stimulate the innovation and entrepreneurship 
students and initiative and creativity, but also to mobilize the enthusiasm of colleges to support innovation and entrepreneurship students and power, many colleges and universities introduced policy measures to support innovation and entrepreneurship students, the university students organized to show the results of innovation and entrepreneurship and rewards innovation and entrepreneurship and create a good atmosphere. People's entrepreneurial innovation in the public tide, university library is facing new tasks, shouldering a new mission, which is to play their own advantages, to provide support in the literature and information services for innovation and entrepreneurship students.

How University Library to shoulder the new historical mission it?

To Recognize New Forms, Clear Service Orientation. The party and government to vigorously promote the public highly innovative new venture situation, direction and content of the University Library Service to make timely adjustments in service-learning, service operations, service exam while increasing service information, service innovation, service orientation and entrepreneurship content.

To Change Their Work Style, Improve Service Enthusiasm. From passive service, waiting service, static service becomes active service, advanced services and dynamic service.

To Improve Working Methods and Enhance Service Levels. To the traditional services, paper service, regular service into a modern services, network services, fixed services.

To Adjust the Index, Guide Service Change. According to the development of the situation, the construction and improvement of library service evaluation system. "Evaluation of a library collection construction must be comprehensive index, which requires both macro indicators, but also a micro indicators. In addition to the total amount of books, you should also examine the content of the books, the collection structure, organization of collections management and utilization. quality is the main basis for the use of books, because books itself quality content, structure, quality and organizational management quality, ultimately to be tested in practice by using the reader "[5] it is necessary to examine the literature and information resource efficiency into documents information resources to meet the user's level, but also examine the degree of resource efficiency and Document information Document information resources are used, including the utilization of literature, literature circulation rate, reading rate, CTR electronic resources [6]

\section{New Path of Private University Library Service Innovation Business Students}

Private College Library Services Students entrepreneurial innovation, the need to reform the traditional service model, to try new services, opening up new paths of service, improve service quality and level. Specifically, at least try the following path.

Establishment Services Entrepreneurial Innovative Ideas. Thought is the forerunner of change, ideas is the premise. Private University Library Service to do business students innovative concrete work, we must first realize the shift in thinking, new ideas on setting up the service business students innovative new ideas, consciously work into the library to cultivate application talents the main channel, clearly Private University Library not only is the service sector, but also shoulder the sacred responsibility of educating people, information resources, space environment, practical training and information quality education side and has irreplaceable advantages and potential, is applied talents important position and college students innovation and entrepreneurship [7]. Library personnel training system is not in the "other", but the implementation of those educational goals, the main force of entrepreneurial innovation and personnel training. Establish this concept, and with the concept of unity of thought and action that librarians, the library will be able to focus shifted to service innovation and entrepreneurship training applied talents come up, to be able to achieve unity of thinking in unison, work place, service quality, the contribution of intelligence in the service business students innovative and application-oriented talents training process.

Establish A Network Information Service Platform. To students start high-quality innovative services, Private University Library must improve service means to improve service processes, to build a new platform. Use of network technology to build information service system, warm, fast, 
high-quality and efficient provision of documentation information services, provide more references for college students entrepreneurship and innovation, drawing on typical role models, to help students successfully carry out entrepreneurial innovation activities to promote adult college students taught.

Build Four in One Service Network. Private College Library business students innovative services, not alone, alone his own power, and college students to entrepreneurship and innovation centers, community college students, college students unite science and technology management, team work, coordination and cooperation, work together, innovation and entrepreneurship for college students Construction of high-quality and efficient service network, forming multi-channel collaboration services together to create business students innovative service brand, for college students entrepreneurship and innovation to create a good environment and conditions of service. Help students in entrepreneurship and innovation project topics, the selection of supervisors, project application, project implementation, the results of identification, foreign exchange, business cooperation, the promotion of all aspects of application, are able to successfully achieve results fast, continue to train college students to get a sense of success and happy, healthy college students venture to promote sustained innovation activities pursued.

To Carry out One Double Hit Information Services. Students start the service innovation process, private university library, not only to focus on the overall surface of the service, but also to pay attention to one service point. To track students start the project implementation process of innovation, according to the characteristics of different projects, different needs of students, provide personalized service, customized to solve problems, to achieve a breakthrough personalized, one by one only to provide quality services to meet the needs of students one by one, one by one made of entrepreneurial innovation progress, innovation and entrepreneurship Students outlook whole school to be able to bang, prosperity, achieved remarkable success. Carry out one to one personalized service, pay attention to the requirements of Private College Librarians self-cultivation, improve their own quality, improve service capabilities, improve service quality, service brand, to build a rational structure, energy level matching, good quality, service place information services team. Private Colleges willing claim in the library hardware construction investment, increase of library, improve document structure, improve services, and create a good service environment.

To carry out these services, we must realize the Sustainable Development of Private University Library. Sustainable Development of Private University Library is to develop application-oriented talents, promote business students innovative infrastructure projects. Library to achieve sustainable development, the key lies in the establishment of the dynamic mechanism of the development of science, the library has the potential to ensure long-term development, so that the library between internal (people, and objects), to create a harmonious society and between libraries interaction. Library capacity for sustainable development covers three areas: collection of information resources and capabilities First Document Library reserves; the second is the library literature information resources processing and management capabilities; third is the development of the library literature information resources, restructuring and capacity utilization. Library achieve sustainable development is to strengthen the construction of hardware and software library for readers to create a "positive" learning environment, "convenient" technological environment, "Dead Poets Society" moral environment and the "clean elegant," ecosystem.

\section{References}

[1] Information on http://www.ce.cn

[2] Information on http: //www.gov.cn

[3] Information on http://education.news.cn

[4] Information on http://www.moe.gov.cn

[5] J.B.In and B.S.Lin: library collection Quality Evaluation .Jilin Forestry College, vol. 4 (1990) NO.3, p102-104. 
[6] X.X.Liang: Evaluation Index System and Empirical Study of Literature Information Resources Allocation Efficiency [J] Library Theory and Practice, vol. 3(2013) NO.3, p38-39.

[7] Xiao ice advantage in the application of Private University Library in Talents .Lanzhou Institute of Education, vol.7 (2015)N0. 1, p.68-69.

[8] H.Y.Zhang:Research.Sustainable Development in Shandong Province Private University Library Library Research. vol.4 (2013)NO.3, p. 16-18. 